\title{
How elite-level soccer dynamics has evolved over the last three decades? Input from generalizability theory
}

\section{¿Cómo ha evolucionado la dinámica del fútbol de élite en los últimos treinta años? Aplicación desde la teoría de la generalizabilidad}

\section{Como tem a dinâmica do Futebol de elite evoluído ao longo das últimas três décadas? Aplicação da Teoria da Generabilidade}

\author{
Daniel Barreira ${ }^{1, *}$, Júlio Garganta ${ }^{1}$, Julen Castellano², João Machado ${ }^{3}$ y M. Teresa Anguera ${ }^{4}$
}

\begin{abstract}
${ }^{1}$ Centre of Research, Education, Innovation and Intervention in Sport (CIFI'D), Faculty of Sport, University of Porto (Portugal), ${ }^{2}$ Department of Physical and Sport Education, Faculty of Physical Activity and Sport Sciences, University of the Basque Country (UPVIEHU) (Spain), ${ }^{3}$ Laboratory of Human Performance Studies, Federal University of Amazonas (Brazil) y ${ }^{4}$ Department of Methodology of Behavioural Sciences, IR3C Research Institute, University of Barcelona (Spain)
\end{abstract}

\begin{abstract}
Soccer dynamics have evolved in response to environmental factors such as match status, type of competition, and competition stage. Observational analysis has shed light into the behavior of players, but few researchers have looked at the complexity of the interactions between players and their teams over time. Here we investigated the variables influencing the patterns of play and the evolution of tactical and technical behaviors through the last three decades. A retrospective inferential study was applied. SoccerEye observational instrument and recording software were used to observe and record 45 matches and 6791 attacks from European and World Cup semi-finals and finals between 1982 and 2010. Publicly available broadcast footage was used for the analysis. Generalizability theory was used as the basis of the statistical analysis. The patterns of play changed by $31.4 \%$ from 1982 to 2010 . Team dynamics were influenced by match status (28.0\%), competition stage (26.5\%), and game period (18.1\%). During the last decade (2002-2010), teams tended to use less the dribble and running with the ball but to increase long passing rate. During 2002-2010 decade, the frequency of attacks down the wings was higher than in 1982-2000, probably a result of the numerical disadvantage of the attacking team in the area of play. Soccer dynamics have changed towards more teamwork and less individual work over the last 30 years. However, not only time, but also match status, competition stage, and game period have influenced the patterns of play.
\end{abstract}

Key words: Association football; attacking; motion recording software; observational methodology; situational variables.

Resumen: La dinámica del fútbol ha evolucionado como respuesta a factores ambientales tales como el resultado de los partidos, tipo y etapa de la competición. La metodología observacional ha permitido analizar el comportamiento de los jugadores, pero pocos investigadores han examinado las interacciones entre los jugadores y los equipos a lo largo del tiempo. En este trabajo se ha investigado acerca de las variables que influyen la evolución de los comportamientos tácticos y técnicos a lo largo de las tres últimas décadas. El instrumento de observación construido y el programa informático SoccerEye permitieron observar y registrar 45 partidos y 6.791 ataques de semifinales y finales de las Eurocopa UEFA y de las Copas del Mundo FIFA entre 1982 y 2010. El análisis estadístico se basó en la aplicación de la Teo-

Dirección para correspondencia [Correspondence address]: Daniel Barreira. Faculdade de Desporto da Universidade do Porto. Rua Dr. Plácido Costa 91. 4200.450 Porto (Portugal).E-mail: dbarreira@fade.up.pt ría de la Generalizabilidad. Los patrones de juego se modificaron en 31,4\% desde 1982 hasta 2010, mientras que el resultado, la fase de competición y el período de partido influyeron en el juego en el $28,0 \%, 26,5 \%$ y $18,1 \%$, respectivamente. Entre 2002 y 2010, los equipos tienden a utilizar menos el drible y conducción del balón, pero aumentó la frecuencia de pase largo. También, el número de ataques por las bandas fue mayor que en 1982-2000, y se trata probablemente de una consecuencia de la desventaja numérica en el centro de juego. La dinámica del fútbol ha cambiado hacia un mayor trabajo en equipo en los últimos 30 ańos. Sin embargo, no sólo el tiempo, sino también el resultado, la etapa de la competición, y el período de juego han influido en los patrones de juego.

Palabras clave: Fútbol de élite; ataque; software de registro; metodología observacional; variables situacionales.

Resumo: A dinâmica do jogo de Futebol tem evoluído devido a fatores ambientais como o resultado, o tipo e a fase da competição. Através da utilizaçáo da análise observacional, verificou-se que o comportamento dos jogadores tem vindo a alterar-se. Contudo, escasseiam investigaçôes acerca das interaçóes entre os jogadores e as equipas ao longo do tempo. Neste estudo analisaram-se as variáveis que parecem influenciar a evoluçấo tática e técnica dos jogadores de Futebol ao longo das últimas três décadas. Utilizaram-se os instrumentos de observaçáo e de registo SoccerEye para registar 45 jogos e 6791 ataques referentes às meias-finais e finais dos Campeonatos da Europa UEFA e do Mundo FIFA de Futebol entre 1982 e 2010. Utilizou-se a teoria da generabilidade como a base para a análise estatística dos dados. Os padrôes de jogo alteraram-se em 31.4\% desde 1982 até 2010, enquanto o resultado, a fase da competição e o período do jogo influenciaram em $28.0 \%, 26.5 \%$ e $18.1 \%$ as alteraçóes, respetivamente. Entre 2002 e 2010, utilizou-se menos o drible e a conduçáo de bola e, inversamente, aumentou-se a utilizaçáo do passe longo, i.e., predomina atualmente um jogo mais coletivo. Já a quantidade de ataques pelos corredores laterais aumentou relativamente ao período 1982-2000, como consequência da desvantagem numérica no centro do jogo. Náo obstante o fator tempo ser o maior responsável pelas alteraçóes dos padrōes de jogo ao longo dos últimos 30 anos, o resultado do jogo, a fase da competiçấo e o período do jogo parecem também ter influenciados.

Palavras chave: Futebol de elite; ataque; software de registo; metodologia observacional; variáveis situacionais. 


\section{Introduction}

Soccer dynamics have evolved not only as a result of improved player performance and technique but also in response to environmental factors such as match status, type of competition, competition stage, and quality of the opponent team (Lago, 2009). To successfully deal with these constraints, contemporary elite soccer players are required to have high versatility and motor ability, as well as rapid information processing and decision-making (Wallace \& Norton, 2014).

A better understanding of the evolution of behavioral patterns in competitive play over time has arisen from observational analysis. For instance, it is known that effective playing time and rhythm has increased from the 1990 FIFA World Cup to the 2008 European Cup (Castellano, Perea, \& Álvarez, 2009). Similarly, game stoppages became longer between the 1966 and the 2010 FIFA World Cup (Wallace \& Norton, 2014). Set plays increased along with the increased use of defensive strategies and balance between teams (Bloomfield, Jonsson, Polman, Houlahan, \& O’Donoghue, 2005), which in turn resulted in higher player density and congestion in the centre of the game (Norton, 2013). In friendly and FIFA World Cup matches (1953, 1974, 1998, and 2002), the distance covered by players, goalkeeper participation, first touch style of play, ball speed, and successful long passing have increased over time (Kuhn, 2005). However, notational methods of observational analysis are limited in their scope to describe and predict the complex interactions of events that occur between players and the environment over time (Duarte et al., 2010). This might provide an explanation as to why some authors have failed to find differences in defending and attacking behaviors (e.g. pass, running with the ball, reception, shot) (Poyatos, 1994; Barreira, Garganta, Castellano, Prudente, \& Anguera, 2014) or in the patterns of field space position and interaction (Castellano, Perea, \& BlancoVillaseñor, 2009).

Only few temporal performance studies have investigated the occurrence of consistent and recognizable patterns of play (Wallace \& Norton, 2014), which could reveal performance indicators that, for instance, could explain the average reduction of 1.66 goals per game from Uruguay 1930 to Germany 2006 (Castellano, Perea, \& Hernández-Mendo, 2008). However, no variables other than time have been taken into account. To overcome this limitation, generalizability theory started being adopted for its capacity to identify components of variance and their interactions (Blanco-Villaseñor, Castellano, \& Hernández-Mendo, 2000; Blanco-Villaseñor, Castellano, Hernández-Mendo, Sánchez-López, \& Usabiaga, 2014). In addition, it allows one to identify and estimate the extent of potentially important sources of error in a measurement (Shavelson, Webb, \& Rowley, 1989). In soccer settings, generalizability theory has been applied to investigate the influence of variables such as competition, interactional context, result, and play zone in performance (Blanco-Villaseñor et al., 2000; Castellano, Perea, \& Blanco-Villaseñor, 2009).

The aims of this study were: (i) to identify the variables that have shaped the patterns of play over time; and (ii) to describe and explain the evolution of tactical and technical behaviors, as well as the structural and interactional configuration of elite-level soccer played in the last 30 years of European and World Cup matches.

\section{Method}

Observational methodology was used to allow for direct observation and recording of spontaneous attacking soccer drills in their natural setting (Sánchez-Algarra \& Anguera, 2013). The study was approved by the Ethics Committee of the Faculty of Sport, University of Porto (CEFADE 10/2012).

\section{Design}

The observational design, in accordance with the specific taxonomy, was nomothetic (6791 attacking drills performed by 60 teams were recorded from the FIFA World Cups between 1982 and 2010), followed-up (continuous recording across matches, with independent observation of each of the two opposing teams) and multidimensional (seven criteria included in the observational instrument) (Anguera, BlancoVillaseñor, Hernández-Mendo, \& Losada, 2011).

\section{Participants}

A successful team is one that reaches the semi-final rounds in elite competitions (Grant, Williams, Reilly, \& Borrie, 1998). Therefore, in this study, we retrospectively analyzed UEFA European Cup and FIFA World Cup semi-finals and finals from 1982 to 2010. Publicly available broadcast footage was used for the analysis. Periods of no observation due to technical and/or technological reasons (e.g. sequences in which the players left the camera's recording field) did not exceed $10 \%$ of total observation time. Extra-time periods and sequences in which the team was playing with 10 elements or less were also excluded from the analysis. A total of 45 matches (90 observations), 6791 attacking drills (75.5 \pm 17.0 per match), and 70,000+ multi-events were recorded. When considered per decade, 2065 (68.8 \pm 14.4 per match), $2526(84.2 \pm 18.9$ per match), and $2200(73.3 \pm 14.2$ per match) attacking drills were recorded in 1982-1990, 1992-2000, and 2002-2010, respectively (Table 1 ). 
Table 1. Attacking drills recorded per competition and per decade from 1982 to 2010.

\begin{tabular}{|c|c|c|c|}
\hline Competition & Matches & Attacks & Multi-events \\
\hline \multicolumn{4}{|l|}{$1982-1990$} \\
\hline 1982 Spain World Cup & 3 & 436 & 5524 \\
\hline 1984 France European Cup & 3 & 472 & 5574 \\
\hline 1986 Mexico World Cup & 3 & 378 & 4294 \\
\hline 1988 Germany European Cup & 3 & 448 & 4746 \\
\hline \multirow[t]{2}{*}{1990 Italy World Cup } & 3 & 331 & 3708 \\
\hline & 15 & 2065 & 23846 \\
\hline \multicolumn{4}{|l|}{ 1992-2000 } \\
\hline 1992 Sweden European Cup & 3 & 458 & 4481 \\
\hline 1994 USA World Cup & 3 & 540 & 5966 \\
\hline 1996 England European Cup & 3 & 422 & 4764 \\
\hline 1998 France World Cup & 3 & 470 & 5114 \\
\hline 2000 Belgium-The Netherlands European Cup & 3 & 636 & 6110 \\
\hline Total & 15 & 2526 & 26435 \\
\hline \multicolumn{4}{|l|}{$2002-2010$} \\
\hline 2002 Korea-Japan World Cup & 3 & 384 & 3666 \\
\hline 2004 Portugal European Cup & 3 & 443 & 4237 \\
\hline 2006 Germany World Cup & 3 & 574 & 5578 \\
\hline 2008 Austria-Switzerland European Cup & 3 & 363 & 4530 \\
\hline 2010 South Africa World Cup & 3 & 436 & 5171 \\
\hline Total & 15 & 2200 & 23182 \\
\hline Total (1982-2010) & 45 & 6791 & 73463 \\
\hline
\end{tabular}

\section{Instruments}

SoccerEye, an observational and recording software tool that permit the detection of behavioral patterns in sport settings, has been described in detail and referred to elsewhere (Barreira, Garganta, Castellano, \& Anguera, 2013; Barreira, Garganta, Guimarães, Machado, \& Anguera, 2014; Barreira, Garganta,
Prudente, \& Anguera, 2012). Briefly, SoccerEye includes 80 categories distributed across seven criteria: 1) Start of offensive phase; 2) Development of defence/attack transition state; 3) Progress of ball possession; 4) End of offensive phase; 5) Pattern of pitch space position (a structural criterion); 6) Centre of the game (an interactional criterion); and 7) Spatial pattern of interaction between teams (also an interactional criterion) (Table 2).

Table 2. SoccerEye observational instrument distribution of categories (per criterion and sub-criterion).

\begin{tabular}{lll}
\hline Criteria & Sub-criteria & Number of categories \\
\hline 1. Start of offensive phase/Ball recovery & 1.1 Direct/dynamical ball recovery & 4 \\
& 1.2 Indirect/static ball recovery & 6 \\
2. Development of defence/attack transition state & & 14 \\
3. Progress of ball possession & & 19 \\
4. End of offensive phase & 4.1 With efficacy & 4 \\
& 4.2. With no efficacy & 4 \\
5. Pattern of pitch space position & & 12 \\
6. Centre of the game & 6.1. With pressure & 3 \\
& 6.2. With no pressure & 3 \\
7. Spatial pattern of interaction between teams & & 11 \\
Total & & 80 \\
\hline
\end{tabular}


For each attacking drill, match status, competition stage, match time, attack duration, and starting time, among other parameters, were recorded using SoccerEye (v3.2) motion recording software (Barreira, Garganta, Castellano, et al., 2013).

SDIS-GSEQ software (v5.1) was used to analyze data quality. SAGT $(v 1.0)$ and SPSS (v20.0) statistical software were applied to estimate the percentage of variability as well as their various interactions, and to check for differences between SoccerEye categories across the three decades considered, respectively.

\section{Procedure}

Data quality. Inter-observer reliability was calculated to assess data quality. Cohen's kappa index $(\mathrm{k})$ was calculated from the observations of the second half of 1990 FIFA World Cup semi-final (Italy vs. Argentina). SDIS-GSEQ software $(v 5.1)$ yielded values of $0.80<\mathrm{k}<0.95$, taking in consideration the lowest and the highest values of the 15 sets of data used for inter-observer reliability calculation. Mean k $(0.89 \pm 0.04)$ was well above the value of 0.75 indicative of high data quality (Fleiss, 1981). In addition, an analysis of each criterion of the observational tool was performed. Criteria 2 and 6 showed the lowest mean k values: $0.90 \pm 0.04$ and $0.89 \pm 0.07$, respectively; and criteria 1,4 , and 5 the highest mean $\mathrm{k}$ values: $0.95 \pm 0.03,0.94 \pm 0.02$, and $0.94 \pm 0.03$, respectively.

Statistical analysis. Following the principles of the generalizability theory (Cronbach, Gleser, Nanda, \& Rajaratnam, 1972), the multi-faceted model, decade*competition stage*halves of the match*match status ${ }^{*}$ criteria $\left(D^{*} \mathrm{C}^{*} \mathrm{H}^{*} \mathrm{~S}^{*} \mathrm{Y}\right)$, was used to detect trends in soccer dynamics across the last three decades. The variance components and the accuracy of generalizations were analyzed according to measurement plan CHSY/D, where D is the instrumentation facet, and C, H, S, and $\mathrm{Y}$ are the differentiation facets. Each SoccerEye criterion was analyzed individually, resulting in seven separate analyses (Table 3). Each facet was divided into several levels as follows:

- Decade (D): 1982-1990, 1992-2000, and 2002-2010;

- Competition stage (C): Semi-final and final rounds;

- Halves of the match (H): First half and second half (Barreira, Garganta, Pinto, Valente, \& Anguera, 2013);
- Match status (S): Winning, drawing, and loosing teams (Castellano, Perea, \& Blanco-Villaseñor, 2009; Taylor, Mellalieu, James, \& Shearer, 2008);

- Criteria (Y): The seven criteria of SoccerEye observational instrument (Barreira et al., 2012).

Based on previous studies (Mushquash \& O'Connor, 2006; Reina-Gómez, Hernández-Mendo, \& FernándezGarcía, 2009; Blanco-Villaseñor et al., 2014), we applied the generalized linear model (GLM) using SAGT $v 1.0$ (Hernández-Mendo, Ramos-Pérez, \& Pastrana, 2012; HernándezMendo et al., 2014). We estimated the percentage of variability (explained variance) for each of the variables as well as their various interactions. Complementarily, descriptive statistics and one-way analysis of variance (ANOVA) were used to compare SoccerEye categories across the three decades considered. Fisher's least significant difference (LSD) post hoc test for multiple comparisons was used to check for specific differences. Statistical significance was set at 0.05 . SPSS $v 20.0$ was used for all analyses.

\section{Results}

The relative $\left(\xi \rho^{2}{ }_{(\delta)}\right)$ and absolute $\left(\xi \rho^{2}{ }_{(\Delta)}\right)$ coefficients of generalizability yielded values between 0.89 and 0.99 for SoccerEye criteria, corresponding to excellent levels of reliability, generalizability, and precision (Castellano et al., 2008). Data were generalizable to a universe score close to 1 .

Overall analysis showed that criteria $(\mathrm{Y})$, alone or in interaction with other variables, such as decade $\left(D^{*} Y\right)$ or decade and match status $\left(D^{*} S^{*} Y\right)$, explained the most variance of the applied model $\left(r^{2} \geq 0.77\right)$ (Table 3$)$. However, the residual error $\left(\mathrm{D}^{*} \mathrm{C}^{*} \mathrm{H}^{*} \mathrm{~S}^{*} \mathrm{Y}\right)$ for criteria 1 (start of offensive phase) and 5 (patterns of pitch space position) $-19.6 \%$ and $6.7 \%$, respectively - alerted us to the fact that more variables should be included to completely explain the variability of the model. Hence, taking in consideration the influence of the other variables-decade, competition stage, halves of the match, and match status - we found that decade explained $31.4 \%$ of the variability in soccer dynamics, followed by match status $(28.0 \%)$, competition stage $(26.5 \%)$, and halves of the match (18.1\%) (Figure 1). 
Figure 1. Soccer dynamics variance explained by decade, competition stage, halves of the match, and match status variables as per criteria of SoccerEye observational instrument.

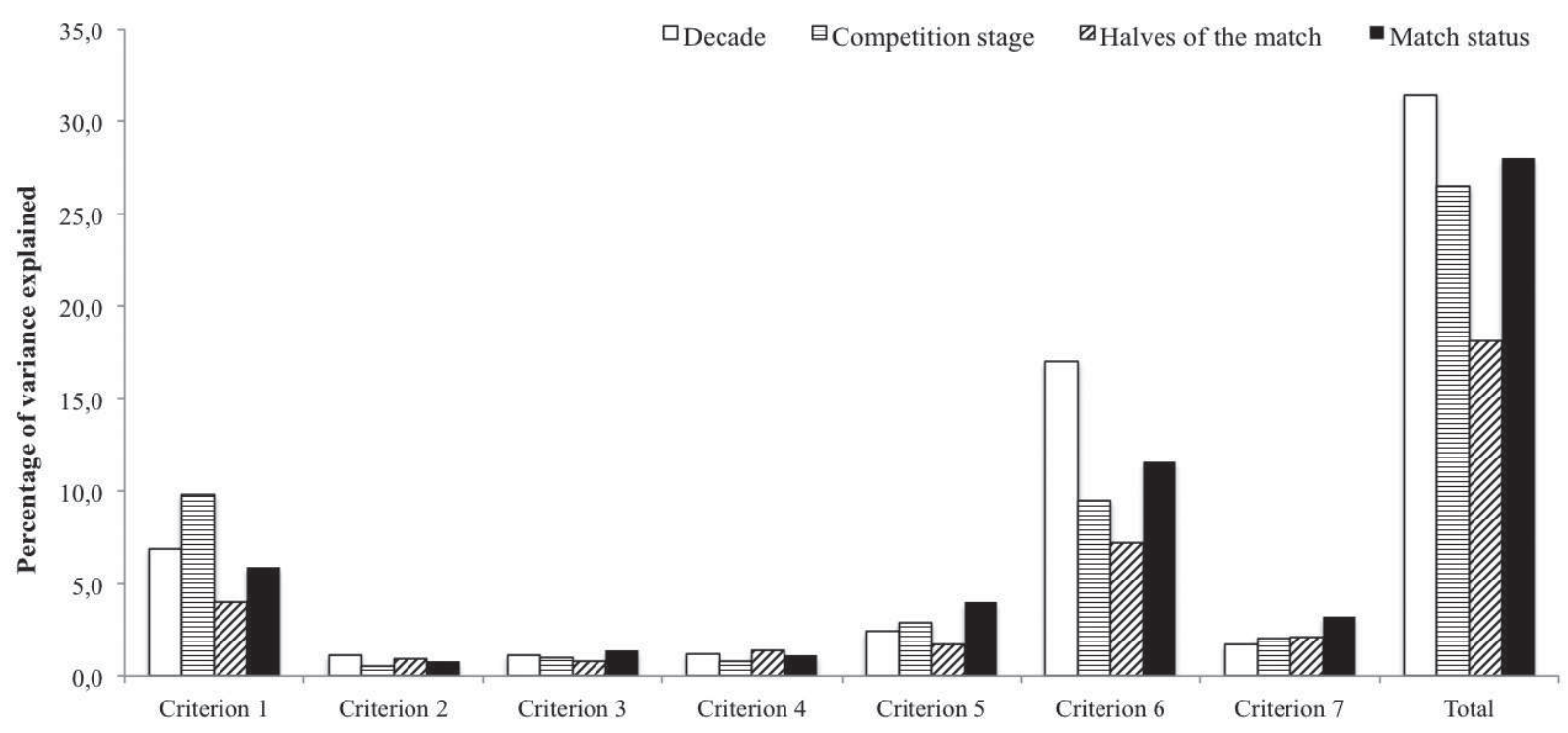

The most influenced criteria by situational variables were the start of offensive phase and the centre of the game: on the one hand, the way the ball was recovered changed in $9.8 \%$ due to competition stage, while decade, match status, and halves of the match exerted less influence $(6.9 \%, 5.9 \%$, and $4.0 \%$, respectively) on the recovery of ball possession; on the other hand, decade $(17.0 \%)$, followed by match status $(11.6 \%)$, competition stage $(9.5 \%)$, and halves of the match $(7.2 \%)$ strongly influenced the variation of numerical contexts at the centre of the game (Figure 1). Moreover, the comparison of defence/attack transition state, progress of ball possession, end of offensive phase, and spatial pattern of interaction between teams revealed that the environment explained no more than $8 \%$ of the variance in playing patterns. The interaction between decade and criteria variables showed that the use of pitch zones $(1.7 \%)$ as well as the player density at the centre of the game (5.6\%) changed over time (Table 3 ). 
Table 3. Analysis of the variance components to each of the SoccerEye observational instrument criterion, according to five factors model: decade*competition stage*halves of the match*match status*criteria.

\begin{tabular}{|c|c|c|c|c|c|c|c|c|c|c|c|c|c|c|}
\hline \multirow[t]{3}{*}{ Variables } & \multicolumn{14}{|c|}{ SoccerEye observational instrument criteria } \\
\hline & \multicolumn{2}{|c|}{$\begin{array}{l}\text { 1. Start of offen- } \\
\text { sive phase }\end{array}$} & \multicolumn{2}{|c|}{$\begin{array}{l}\text { 2. Defence/ } \\
\text { attack transi- } \\
\text { tion-state }\end{array}$} & \multicolumn{2}{|c|}{$\begin{array}{l}\text { 3. Progress of } \\
\text { ball possession }\end{array}$} & \multicolumn{2}{|c|}{$\begin{array}{l}\text { 4. End of offen- } \\
\text { sive phase }\end{array}$} & \multicolumn{2}{|c|}{$\begin{array}{l}\text { 5. Pattern of } \\
\text { pitch space } \\
\text { position }\end{array}$} & \multicolumn{2}{|c|}{$\begin{array}{l}\text { 6. Centre of } \\
\text { the game }\end{array}$} & \multicolumn{2}{|c|}{$\begin{array}{l}\text { 7. Spatial pattern } \\
\text { of interaction } \\
\text { between teams }\end{array}$} \\
\hline & $\overline{\%}$ & $\operatorname{Pr}>\mathrm{F}$ & $\%$ & $\operatorname{Pr}>\mathrm{F}$ & $\%$ & $\operatorname{Pr}>\mathrm{F}$ & $\%$ & $\operatorname{Pr}>\mathrm{F}$ & $\%$ & $\operatorname{Pr}>\mathrm{F}$ & $\%$ & $\operatorname{Pr}>\mathrm{F}$ & $\%$ & $\operatorname{Pr}>\mathrm{F}$ \\
\hline$\overline{\text { Decade (D) }}$ & 0.1 & 0.9992 & 0.0 & 0.9918 & 0.0 & 0.9949 & 0.0 & 0.9965 & 0.0 & 0.9943 & 0.0 & 0.9943 & 0.0 & 0.9949 \\
\hline Stage (C) & 0.3 & 0.9912 & 0.0 & 0.9952 & 0.0 & 0.9725 & 0.0 & 0.9369 & 0.0 & 0.9428 & 0.0 & 0.9929 & 0.0 & 0.9714 \\
\hline$\overline{\mathrm{D}^{*} \mathrm{C}}$ & 0.0 & 0.9995 & 0.0 & 0.9979 & 0.0 & 0.9845 & 0.0 & 0.9999 & 0.0 & 0.9740 & 0.7 & 0.9968 & 0.0 & 0.9780 \\
\hline Halves (H) & 0.1 & 0.9669 & 0.0 & 0.9914 & 0.0 & 0.8208 & 0.0 & 0.9437 & 0.0 & 0.8341 & 0.0 & 0.9829 & 0.0 & 0.9198 \\
\hline$\overline{\mathrm{D}^{*} \mathrm{H}}$ & 0.0 & 0.9996 & 0.0 & 0.9734 & 0.0 & 0.9692 & 0.0 & 0.9970 & 0.0 & 0.9863 & 0.5 & 0.9983 & 0.0 & 0.9874 \\
\hline$\overline{\mathrm{C}^{*} \mathrm{H}}$ & 0.0 & 0.9470 & 0.0 & 0.9163 & 0.0 & 0.9311 & 0.0 & 0.9023 & 0.0 & 0.9364 & 0.4 & 0.9919 & 0.0 & 0.9607 \\
\hline$\overline{\mathrm{D}^{*} \mathrm{C}^{*} \mathrm{H}}$ & 0.0 & 0.9993 & 0.0 & 0.9971 & 0.0 & 0.9815 & 0.1 & 0.9964 & 0.0 & 0.9993 & 0.0 & 0.9993 & 0.0 & 0.9996 \\
\hline Match Status (S) & 0.2 & 0.9998 & 0.0 & 0.9984 & 0.0 & 0.9154 & 0.0 & 0.9995 & 0.0 & 0.9564 & 0.0 & 0.9996 & 0.0 & 0.9777 \\
\hline$\overline{D * S}$ & 0.0 & 10.000 & 0.0 & 10.000 & 0.0 & 0.9984 & 0.0 & 10.000 & 0.0 & 10.000 & 0.6 & 10.000 & 0.0 & 0.9998 \\
\hline $\mathrm{C}^{*} \mathrm{~S}$ & 0.0 & 0.9986 & 0.0 & 0.9942 & 0.0 & 0.9744 & 0.0 & 0.9988 & 0.0 & 0.9964 & 0.8 & 0.9998 & 0.0 & 0.9980 \\
\hline $\mathrm{D}^{*} \mathrm{C}^{*} \mathrm{~S}$ & 0.2 & 0.9999 & 0.0 & 10.000 & 0.0 & 10.000 & 0.0 & 10.000 & 0.0 & 0.9999 & 0.0 & 10.000 & 0.0 & 0.9997 \\
\hline $\mathrm{H}^{*} \mathrm{~S}$ & 0.0 & 0.9989 & 0.0 & 0.9882 & 0.0 & 0.9806 & 0.0 & 0.9992 & 0.0 & 0.9981 & 0.5 & 0.9966 & 0.0 & 0.9761 \\
\hline $\mathrm{D}^{*} \mathrm{H}^{*} \mathrm{~S}$ & 0.3 & 10.000 & 0.0 & 10.000 & 0.0 & 0.9981 & 0.1 & 0.9999 & 0.0 & 0.9999 & 0.0 & 10.000 & 0.0 & 10.000 \\
\hline $\mathrm{C}^{*} \mathrm{H}^{*} \mathrm{~S}$ & 0.2 & 0.9996 & 0.0 & 0.9956 & 0.0 & 0.9960 & 0.0 & 0.9996 & 0.1 & 0.9984 & 0.0 & 0.9998 & 0.0 & 0.9973 \\
\hline $\mathrm{D}^{*} \mathrm{C}^{*} \mathrm{H}^{*} \mathrm{~S}$ & 0.0 & 10.000 & 0.0 & 0.9998 & 0.0 & 0.9932 & 0.0 & 10.000 & 0.0 & 0.9999 & 3.2 & 10.000 & 0.0 & 0.9998 \\
\hline Criteria (Y) & 68.2 & $<0.0001^{*}$ & 95.0 & $<0.0001^{*}$ & 95.1 & $<0.0001^{*}$ & 92.2 & $<0.0001^{*}$ & 84.3 & $<0.0001^{*}$ & 75.9 & $<0.0001^{*}$ & 93.0 & $<0.0001^{*}$ \\
\hline $\mathrm{D}^{*} \mathrm{Y}$ & 0.0 & $<0.0001^{*} \dagger$ & 0.5 & $<0.0001^{*} \dagger$ & 0.0 & $<0.0001^{*} \dagger$ & 0.7 & $<0.0001^{*} \dagger$ & 1.7 & $<0.0001^{*} \dagger$ & 5.6 & $<0.0001^{*} \dagger$ & 0.2 & $<0.0001^{*} \dagger$ \\
\hline $\mathrm{C}^{*} \mathrm{Y}$ & 0.0 & 0.5851 & 0.1 & 0.3160 & 0.0 & 0.0994 & 0.3 & $0.0103^{*}$ & 2.1 & 0.5147 & 0.9 & 0.2797 & 0.0 & 0.1774 \\
\hline $\mathrm{D}^{*} \mathrm{C}^{*} \mathrm{Y}$ & 3.7 & $<0.0001^{*} \dagger$ & 0.0 & 0.9628 & 0.3 & $0.0125^{* \dagger}$ & 0.1 & 0.1802 & 0.1 & $0.0308^{*} \dagger$ & 0.0 & 0.8553 & 0.4 & 0.0758 \\
\hline $\mathrm{H}^{*} \mathrm{Y}$ & 0.0 & 0.7479 & 0.2 & $<0.0001^{*}$ & 0.0 & $0.0010^{*}$ & 0.0 & 0.2342 & 0.7 & $0.0002^{*}$ & 0.8 & 0.0357 & 0.5 & $<0.0001^{*}$ \\
\hline $\mathrm{D}^{*} \mathrm{H}^{*} \mathrm{Y}$ & 0.0 & $0.0056^{*} \dagger$ & 0.2 & $0.0320^{*} \dagger$ & 0.4 & $0.0074^{*} \dagger$ & 0.2 & 0.6676 & 0.0 & 0.4297 & 0.4 & 0.8347 & 0.2 & 0.4084 \\
\hline $\mathrm{C}^{*} \mathrm{H}^{*} \mathrm{Y}$ & 0.0 & 0.0635 & 0.1 & 0.2094 & 0.1 & 0.8043 & 0.0 & 0.9453 & 0.2 & 0.3118 & 0.0 & 0.9945 & 0.0 & $0.0410^{*}$ \\
\hline $\mathrm{D}^{*} \mathrm{C}^{*} \mathrm{H}^{*} \mathrm{Y}$ & 2.2 & $0.0001^{*} \dagger$ & 0.3 & 0.0624 & 0.0 & 0.6642 & 0.0 & 0.4554 & 0.0 & $0.0547^{* \dagger}$ & 0.0 & 0.9945 & 0.0 & 0.8799 \\
\hline$S^{*} Y$ & 0.0 & 0.0767 & 0.6 & $<0.0001^{*}$ & 0.1 & $<0.0001^{*}$ & 0.0 & 0.1423 & 2.9 & $<0.0001^{*}$ & 0.0 & 0.8940 & 1.0 & $<0.0001^{*}$ \\
\hline $\mathrm{D}^{*} \mathrm{~S}^{*} \mathrm{Y}$ & 0.4 & 0.1382 & 0.1 & 0.4507 & 0.4 & $0.0417^{* \dagger}$ & 0.0 & 0.8919 & 0.0 & 0.1791 & 2.1 & $0.0078^{*} \dagger$ & 0.5 & $0.0148^{*} \dagger$ \\
\hline $\mathrm{C}^{*} \mathrm{~S}^{*} \mathrm{Y}$ & 3.4 & $<0.0001^{*}$ & 0.0 & 0.9631 & 0.6 & 0.0219* & 0.0 & $0.0057^{*}$ & 0.4 & 0.3190 & 0.0 & 0.9934 & 0.0 & 0.2255 \\
\hline$D^{*} C^{*} S^{*} Y$ & 0.0 & $0.0085^{* \dagger}$ & 0.0 & 0.3247 & 0.0 & 0.3437 & 0.0 & $0.0024^{*} \dagger$ & 0.0 & $0.0284^{*} \dagger$ & 3.4 & 0.4804 & 0.3 & 0.7028 \\
\hline $\mathrm{H}^{*} \mathrm{~S}^{*} \mathrm{Y}$ & 1.2 & 0.0762 & 0.1 & 0.9520 & 0.3 & $0.0247^{*}$ & 0.6 & $0.0002^{*}$ & 0.0 & 0.6511 & 0.8 & 0.5295 & 0.0 & 0.0941 \\
\hline $\mathrm{D}^{*} \mathrm{H}^{*} \mathrm{~S}^{*} \mathrm{Y}$ & 0.0 & $0.0290^{*} \dagger$ & 0.0 & 0.8723 & 0.0 & 0.7278 & 0.0 & 0.1982 & 0.6 & $0.0012^{*} \dagger$ & 0.5 & 0.9907 & 0.1 & 0.8550 \\
\hline $\mathrm{C}^{*} \mathrm{H}^{*} \mathrm{~S}^{*} \mathrm{Y}$ & 0.0 & 0.1680 & 0.0 & 0.9178 & 0.0 & 0.5461 & 0.4 & $0.0025^{*}$ & 0.0 & 0.8792 & 0.1 & 0.9783 & 1.3 & $0.0145^{*}$ \\
\hline $\mathrm{D}^{*} \mathrm{C}^{*} \mathrm{H}^{*} \mathrm{~S}^{*} \mathrm{Y}$ & 19.6 & $0.0003^{*}$ & 2.7 & 0.3058 & 2.6 & $0.0003^{*}$ & 5.0 & $0.0030^{*}$ & 6.7 & $0.0166^{*}$ & 2.9 & 0.9990 & 2.3 & 0.9314 \\
\hline \multirow[t]{3}{*}{ CHSY/D } & $r^{2}$ & 0.77 & & 0.94 & & 0.96 & & 0.93 & & 0.89 & & 0.77 & & 0.92 \\
\hline & $\xi \rho^{2}{ }_{(\delta)}$ & 0.89 & & 0.99 & & 0.99 & & 0.98 & & 0.97 & & 0.92 & & 0.99 \\
\hline & $\overline{\xi \rho^{2}{ }_{(\Delta)}}$ & 0.89 & & 0.99 & & 0.99 & & 0.98 & & 0.97 & & 0.92 & & 0.99 \\
\hline
\end{tabular}

Note: $\operatorname{Pr}>\mathrm{F}$ : significance level using GLM procedure; \%: variance explained; $\mathrm{r}^{2}$ : coefficient of determination; $\xi \rho_{(\delta)}^{2}:$ generalizability relative coefficient; $\xi \rho_{(\Delta)}^{2}:$ generalizability absolute coefficient

*Significant influence of the variable, or interaction of variables, in the global variation of the model, $\mathrm{p} \leq 0.05$

$\dagger$ Significant influence of the decade variable, in interaction with other variables, in the global variation of the model, $\mathrm{p} \leq 0.05$ 
Because we found that decade explained $31.4 \%$ of the variability in soccer dynamics, we decided to explore the interactions between decade (D) and criteria (Y) further.

Considering the four behavioral criteria (1-4) and their respective categories, we found that the frequency of ball recovery by interception, goal kicks, and throw-ins was higher in the last decade (2002-2010) than in the first decade (19821990) $(\mathrm{p}<0.05)$. Long passes in defence/attack transition state and in progress of ball possession also became more frequent over time; the same was observed with throw-ins $(\mathrm{p}=0.04)$. On the contrary, the frequency of indirect ball recovery by goal kick decreased from 1982-1990 to 1992-2000 ( $\mathrm{p}=0.02$ ). Individual behaviors, i.e. dribble $(1 \times 1)$ in transition state $(p=0.03)$ and running with the ball during the progress of ball possession $(\mathrm{p}=0.05)$, also decreased between first and third decades (Table 4). As for final attacking behaviors, shooting off target decreased between 1982-1990 and 2002-2010 ( $\mathrm{p}=0.04)$ and between 1982-1990 and 1992-2000 ( $\mathrm{p}=0.00)$; there was

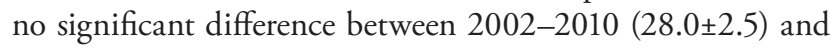

1992-2000 (27.6 \pm 4.7$)$. Interestingly during the last decade (2002-2010: 287.8 \pm 51.1 ), teams lost ball possession due to ball carrier error or opponent intervention more often than in the first years considered $(244.0 \pm 38.4)(\mathrm{p}=0.05)$. The opposite was verified for loss of ball possession due to opponent goalkeeper

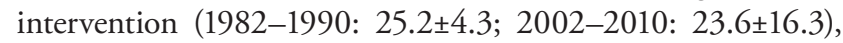
which suggests that teams nowadays often fail to reach the opponent's goal (Table 4).

In what it concerns the structural criterion (patterns of field space position), the use of the central areas of the midfield zone decreased during the last decade (2002-2010) $(\mathrm{p}=0.05)$. This means that the central defensive zone, which is the area where the goalkeeper predominantly stands, is nowadays less used than in the first decade $(p=0.03)$. This is in agreement with the above observation of less frequent opponent goalkeeper intervention. On the other hand, the occurrence of behaviors along the right side line increased during the last years, especially at the right defensive $(\mathrm{p}=0.01)$ and right mid-offensive zones $(\mathrm{p}=0.01)$ (Table 4).

Table 4. Significant differences across the last three decades concerning to SoccerEye behavioral and structural categories. Values are means \pm SD

\begin{tabular}{|c|c|c|c|c|c|}
\hline \multirow{2}{*}{ Criteria } & \multirow{2}{*}{ Categories } & \multirow{2}{*}{$\mathrm{p}$} & \multicolumn{3}{|c|}{ Decades } \\
\hline & & & $1982-1990$ & 1992-2000 & 2002-2010 \\
\hline \multirow[t]{3}{*}{ 1. Start of offensive phase (BR) } & $\mathrm{BRi}^{*}$ & $0.04^{*}$ & $74.6 \pm 19.7$ & $96.2 \pm 18.0$ & $100.2 \pm 20.3$ \\
\hline & $\mathrm{BRgki}^{*} \dagger$ & $0.00^{*} / 0.02 \dagger$ & $51.6 \pm 13.6$ & $47.8 \pm 4.9$ & $38.6 \pm 10.4$ \\
\hline & $\mathrm{BRti}^{*}$ & $0.02^{*}$ & $32.2 \pm 9.4$ & $45.6 \pm 6.1$ & $46.6 \pm 8.3$ \\
\hline \multirow[t]{3}{*}{ 2. Defence/attack transition state (DT) } & DTplp $^{*}$ & $0.03^{*}$ & $3.0 \pm 1.2$ & $4.4 \pm 3.2$ & $10.2 \pm 6.9$ \\
\hline & DTnlp ${ }^{*}$ & $0.00^{*} / 0.05^{\S}$ & $3.8 \pm 2.8$ & $10.0 \pm 4.2$ & $13.8 \pm 6.3$ \\
\hline & $\mathrm{DTd}^{*} \dagger$ & $0.03^{*} / 0.05 \dagger$ & $47.0 \pm 14.9$ & $37.0 \pm 30.3$ & $26.2 \pm 23.2$ \\
\hline \multirow[t]{4}{*}{ 3. Progress of ball possession (DP) } & DPplp ${ }^{*}$ & $0.00^{*} / 0.04^{\S}$ & $6.2 \pm 2.4$ & $12.6 \pm 2.3$ & $22.4 \pm 14.0$ \\
\hline & DPnlp ${ }^{*}$ & $0.01^{*}$ & $9.6 \pm 6.2$ & $17 \pm 5.2$ & $21.4 \pm 10.1$ \\
\hline & $\mathrm{DPrb}^{*}$ & $0.05^{*}$ & $239.2 \pm 105.7$ & $186.0 \pm 63.4$ & $129.4 \pm 41.6$ \\
\hline & $\mathrm{DPti}^{*}$ & $0.04^{*}$ & $55.6 \pm 15.5$ & $62.8 \pm 9.5$ & $70.4 \pm 18.5$ \\
\hline \multirow[t]{4}{*}{ 4. End of offensive phase (F) } & Fws $\dagger$ & $0.04^{*} / 0.00 \dagger$ & $36.0 \pm 7.9$ & $27.6 \pm 4.7$ & $28.0 \pm 2.5$ \\
\hline & Fso ${ }^{*}$ & $0.04^{*}$ & $5.6 \pm 1.7$ & $4.8 \pm 3.1$ & $4.2 \pm 2.0$ \\
\hline & Fled $^{*}$ & $0.05^{*}$ & $244.0 \pm 38.4$ & $317.0 \pm 57.8$ & $287.8 \pm 51.1$ \\
\hline & $\mathrm{Fgk}^{\S}$ & $0.04^{\S}$ & $25.2 \pm 4.3$ & $39.2 \pm 10.1$ & $23.6 \pm 16.3$ \\
\hline \multirow[t]{4}{*}{ 5. Pattern of field space position } & Zone $2^{*}$ & $0.03^{*}$ & $228.8 \pm 46.5$ & $227.4 \pm 39.5$ & $192.8 \pm 40.5$ \\
\hline & Zone $3 \dagger$ & $0.01 \dagger$ & $38.0 \pm 8.5$ & $28.4 \pm 4.0$ & $32.2 \pm 9.5$ \\
\hline & Zone $5^{\S}$ & $0.05^{\S}$ & $412.0 \pm 65.1$ & $497.2 \pm 86.5$ & $394.2 \pm 80.7$ \\
\hline & Zone $9^{*}$ & $0.01^{*}$ & $157.4 \pm 20.1$ & $192.4 \pm 29.9$ & $198.4 \pm 24.8$ \\
\hline
\end{tabular}

BRi: BR by Interception; BRgki: BR by Goal kick; BRti: BR by Throw-in; DTplp: DT by positive long passing; DTnlp: DT by negative long passing; DTd: DT by dribbling (1×1); DPplp: DP by positive long passing; DPnlp: DP by negative long passing; DPrb: DP by running with the ball; DPti: DP by throw-in; Fws: Wide shot; Fso: Shot stopped, with no continuation of ball possession; Fled: Loss of ball possession by error of the ball carrier/defender's intervention; Fgk: Loss of ball possession by intervention of the opponent's goalkeeper; Zone 2: Central defensive zone; Zone 3: Right defensive zone; Zone 5: Central mid-defensive zone; Zone 9: Right mid-offensive zone *Significant between $1982-1990$ and 2002-2010; p $\leq 0.05$ by LSD post hoc test

$\dagger$ Significant between $1982-1990$ and 1992-2000; $\leq 0.05$ by LSD post hoc test ${ }^{\S}$ Significant between $1992-2000$ and $2002-2010 ; \mathrm{p} \leq 0.05$ by LSD post hoc test 
Our analysis showed that teams created less attacking interaction contexts in 2002-2010 than in 1982-1990. Specifically between 1992-2000 and 2002-2010, there was a significant decrease of attacking drills, i.e. the play of the offensive line of the observed team against the opponent's midline $(\mathrm{p}=0.03)$ and against the opponent's goalkeeper $(\mathrm{p}=0.01)$. In the last decade, elite teams have had more difficulties to penetrate into the attacking zone than 30 years ago.

The evolution of player density in the centre of the game (17\% of variance explained by decade facet; Figure 1) showed that relative and absolute numerical inferiority categories

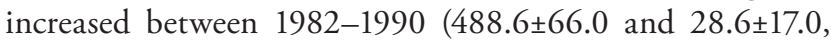

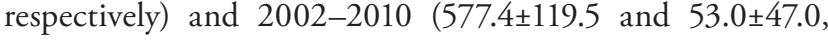
respectively), while the opposite occurred with regards to numerical equality. Indeed, drills with numerical equality in the centre of the game and favorable conditions to continue the attack in the lack of pressure were significantly decreased in the last decade $(p=0.04)$. The number of drills with relative numerical advantage (i.e. 1-2 players more than the opponent team at the centre of the game) decreased between

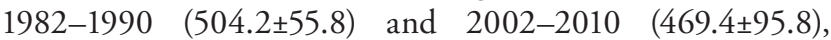
while those with absolute numerical superiority (i.e. $\geq 3$ players more) doubled between the first $(71.8 \pm 23.7)$ and the last (134.2 \pm 129.9$)$ decades $(\mathrm{p}=0.05)$ (Figure 2).

Figure 2. Evolution of the centre of the game across the last three decades. Values are mean \pm SD

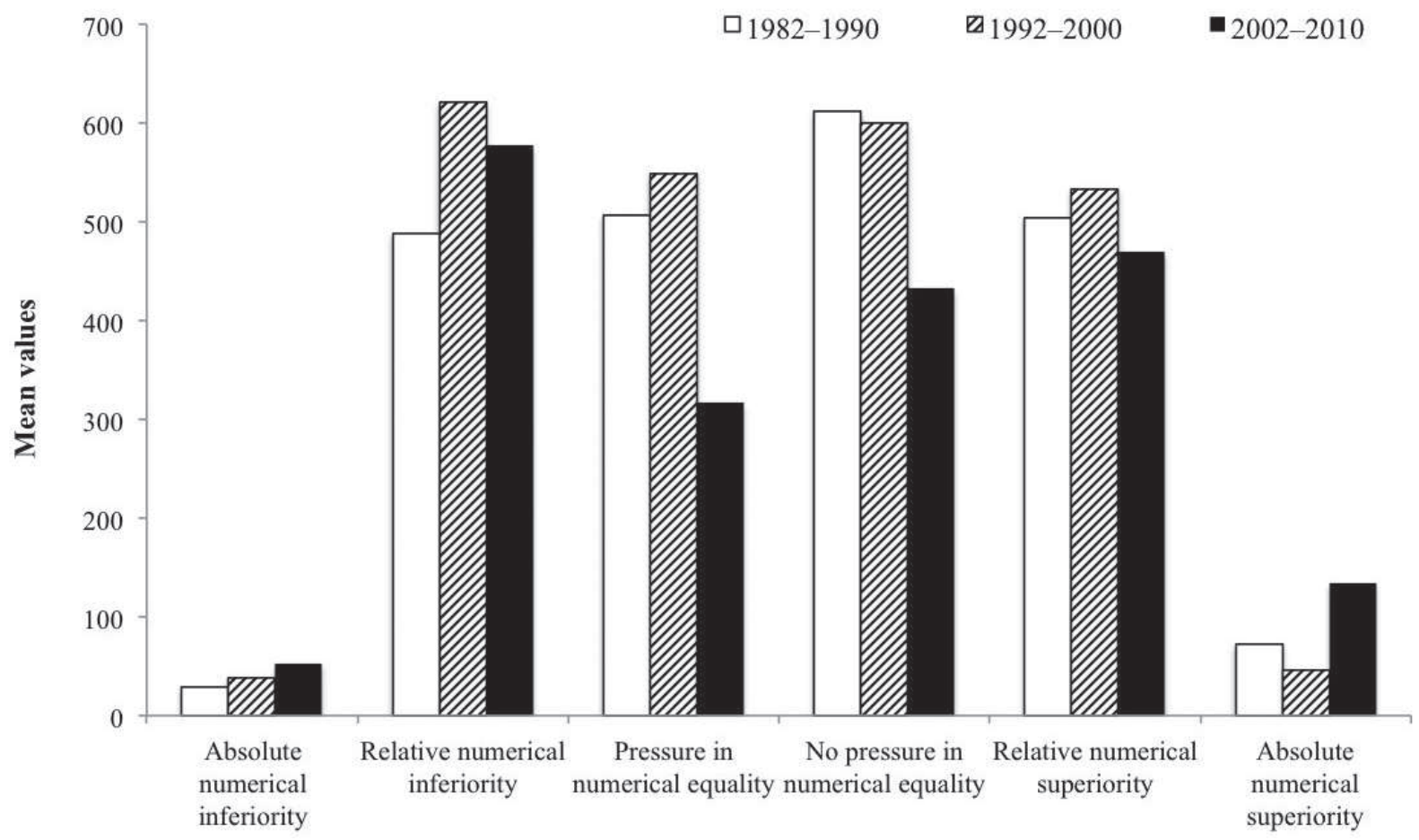

"Significant between $1982-1990$ and 2002-2010; $p \leq 0.05$ by LSD post hoc test

${ }^{\dagger}$ Significant between $1982-1990$ and $1992-2000 ; p \leq 0.05$ by LSD post hoc test

`Significant between $1992-2000$ and $2002-2010$ decades; $p \leq 0.05$ by LSD post hoc test

\section{Discussion}

The coefficient of determination $\left(r^{2} \geq 0.77\right)$ showed that data obtained from the multi-faceted model $\mathrm{D}^{*} \mathrm{C}^{*} \mathrm{H}^{*} \mathrm{~S}^{*} \mathrm{Y}$ explained well the variance of the broad-spectrum taxonomic tool criteria. SoccerEye observational criteria explained most of the variance in soccer dynamics over the past 30 years, followed by time (decade).

When considered the influence of each individual variable, criteria (Y) explained most of the variance of the model, probably because of their heterogeneity. Criterion 7 (spatial patterns of team interaction) revealed the highest value (97.5\%). Our findings corroborate with other studies that found that variance was highly explained by interactional contexts (Castellano, Perea, \& Blanco-Villaseńor, 2009; Castellano et al., 2008; Losada, 2012). The division of the soccer pitch into 12 zones explained $93 \%$ of the model variance. This value was higher than the $54 \%$ obtained for the 5-zone division used 
in previous research (Castellano, Perea, \& Blanco-Villaseñor, 2009; Losada, 2012).

Values of the explained variance of soccer dynamics were in the order: decade $(31.4 \%)$, match status $(28.0 \%)$, competition stage $(26.5 \%)$, and halves of the match $(18.1 \%)$. These results confirmed recent research that reported the importance of time (Kuhn, 2005; Wallace \& Norton, 2014), match status (winning, loosing, and drawing) (Lago, 2009; Taylor et al., 2008), competition stage (Barreira, Garganta, Machado, \& Anguera, 2014), and game period (Barreira, Garganta, Pinto, et al., 2013; Pratas, Volossovitch, \& Ferreira, 2012).

The start of the attack and the centre of the game were the most influenced by the above-mentioned variables. The way the ball was recovered across the last 30 years was influenced by competition stage in $9.8 \%$. This corroborates with previous research showing that direct types of ball recovery, in particular interceptions, tackles, and defensive actions followed by passes, were significantly different in group and play-off stages of FIFA World Cup 2010 (Barreira, Garganta, Guimarães, et al., 2014). In 1986 FIFA World Cup, the playing styles were influenced by the competition stage(Pollard $\&$ Reep, 1997). Decade and halves of the match explained $6.9 \%$ and $4.0 \%$ of the variance, respectively. Player density was also affected by situational variables. Although we found that $17.0 \%$ of the variance occurred due to the decade facet, match status (11.6\%) also exerted high effect on the behaviors of players and their teams. For instance, match status explained $5.9 \%$ of ball recovery variance, confirming a study that reported that winning teams predominantly recover ball possession in mid-defensive zones, while loosing teams tend to recover the ball in the mid-offensive pitch sector (Barreira, Garganta, \& Anguera, 2011). After scoring, a team tends to use a more defensive strategy, i.e. decreased ball possession and increased counter-attacking or direct play; in the defensive half of the pitch, however, ball possession increases (Barreira et al., 2011; Lago \& Martín, 2007).

The numerical contexts in the centre of the game have changed over the last three decades, confirming results obtained for elite-level Australian football, rugby union, and soccer (Norton, 2013). We also found that modern elite teams had more difficulties to create favorable numerical contexts in the area of play than in the past, i.e. the relative and absolute numerical inferiority of the attacking team increased in 2002-2010, while the numerical equality and relative numerical superiority contexts between attacking and defending teams have decreased. The absolute numerical superiority was the exception to this trend, significantly increasing its occurrence in 2002-2010, probably due to the evolution towards greater hang back defensive strategies. More defensive strategies at defensive and mid-defensive lines have probably led to fewer attacking drills in comparison with 30 years ago. The goalkeeper appeared to be less participative, which is in agreement with the observation that increased player density might be related to better defensive strategies (Wallace \& Norton, 2014).

Higher player density has increased pressure in the centre of the game, thus increasing the complexity of the decision-making process. For instance, in soccer the probability of scoring doubles for every meter of free space around the shooter when shooting for goal (Pollard, Ensum, \& Taylor, 2004). To overcome this issue, teams have increased the passing rates (11.3 passes/min in 1966 and 15.3 passes/min in 2010) (Wallace \& Norton, 2014). Our results confirmed that long passing increased, and individual behaviors decreased over time.

\section{Practical implications}

In the present study we intended to identify the variables influencing the patterns of play and the evolution of tactical and technical behaviors, as well as the structural and interactional configuration over the last 30 years of European and World Cup soccer matches through the last three decades.

Contemporary soccer implies teamwork, the collective commitment in the search for a shared objective: winning, which is expressed by less individual behaviors and increased passing rate. This might be a response to repeated numerical disadvantage of attacking teams in the centre of the game. Consequently, contemporary teams operate on the wings, which has probably increased the frequency of throw-ins. Nevertheless, attacking drills are less frequent, a possible consequence of increased congestion in the midfield during defensive tactics. In summary, the playing patterns have changed to allow players and teams to move successfully through high-density field areas during attacking drills.

In summary:

- With generalizability theory it is possible to understand how situational variables influence the behavior of successful elite soccer teams.

- The behavioral, structural, and interactional patterns reveal the attacking strategies of the studied teams.

- The prediction of the attacking behavior of future teams based on evolution trends might help tailor training programs.

Acknowledgments: The first author was supported by Fundação Portuguesa para a Ciência e a Tecnologia (Grant SFRH/BD/48558/2008). This research was also supported by Spanish government project "Observación de la interacción en deporte y actividad física: Avances técnicos y metodológicos en registros automatizados cualitativos-cuantitativos" (Secretaría de Estado de Investigación, Desarrollo e Innovación del Ministerio de Educación y Ciencia, Grant DEP2012-32124).We gratefully acknowledge the support of 
the Catalan government project Grup de recerca i innovació en dissenys (GRID). Tecnologia $i$ aplicació multimedia $i$ digital als dissenys observacionals (Grant number 2014 SGR 971).
Statement of conflicts of interest: The authors state no conflict of interest.

\section{References}

1. Anguera, M. T., Blanco-Villaseñor, A., Hernández Mendo, A., y Losada, J. L. (2011). Diseńos observacionales: ajuste y aplicación en psicología del deporte. Cuadernos de Psicología del Deporte, 11(2),63-76.

2. Barreira, D., Garganta, J., \& Anguera, M. T. (2011). In search of nexus between attacking game-patterns, match status and type of ball recovery in European Soccer Championship 2008. In M. Hughes, H. Dancs, K. Nagyváradi, T. Polgár, N. James, G. Sporis, G. Vuckovic \& M. Jovanovic (Eds.), Research Methods and Performance Analysis. 5th International Christmas Sport Scientific Conference: Qualitative and Quantitative Research in Sport Science (pp. 226-237). Szombathely, Hungary.

3. Barreira, D., Garganta, J., Castellano, J., \& Anguera, M. T. (2013). SoccerEye: A Software Solution to Observe and Record Behaviours in Sport Settings. The Open Sports Sciences Journal, 6, 47-55.

4. Barreira, D., Garganta, J., Castellano, J., Prudente, J., y Anguera, M.T. (2014). Evolución del ataque en el fútbol de élite entre 1982 y 2010: Aplicación del análisis secuencial de retardos. Revista de Psicología del Deporte, 23(1), 139-146.

5. Barreira, D., Garganta, J., Guimarães, P., Machado, J., \& Anguera, M. T. (2014). Ball recovery patterns as a performance indicator in elite soccer. Proc IMechE Part P: J Sports Engineering and Technology, 228(1), 61-72.

6. Barreira, D., Garganta, J., Machado, J., \& Anguera, M. T. (2014). Effects of ball recovery on top-level soccer attacking patterns of play. Revista Brasileira de Cineantropometria e Desempenho Humano, 16(1), 36-46.

7. Barreira, D., Garganta, J., Pinto, T., Valente, J., \& Anguera, M. T. (2013). Do attacking game patterns differ between first and second halves of soccer matches in the 2010 FIFA World Cup? In H. Nunome, B. Drust \& B. Dawson (Eds.), Science and Football VII: The Proceed ings of the Seventh World Congress on Science and Football (pp. 193-198). London and New York: Routledge.

8. Barreira, D., Garganta, J., Prudente, J., e Anguera, M. T. (2012). Desenvolvimento e validação de um sistema de observaçáo aplicado à fase ofensiva em Futebol: SoccerEye. Revista Portuguesa de Ciências do Desporto, 12(3), 32-57.

9. Blanco-Villaseñor, A., Castellano, J., y Hernández-Mendo, A. (2000). Generalizabilidad de las observaciones de la acción del juego en el fútbol. Psicothema, 12(supl. 2), 81-86

10. Blanco-Villaseñor, A., Castellano, J., Hernández-Mendo, A., Sánchez, C.R, y Usabiaga, O. (2014). Aplicación de la TG en el deporte para el estudio de la validez, fiabilidad y estimación de la muestra. Revista de Psicología del Deporte, 23(1), 131-137.

11. Bloomfield, J., Jonsson, G., Polman, R., Houlahan, K., \& O’Donoghue, P. (2005). Temporal Pattern Analysis and its Applicability in Soccer. In L. Anolli, S. Duncan Jr., M. S. Magnusson \& G. Riva (Eds.), The Hidden Structure of Interaction: From Neurons to Culture Patterns (pp. 238-251). Amsterdam: IOS Press.

12. Castellano, J., Perea, A., \& Álvarez, D. (2009). Transicions en la possessió de la pilota en futbol: del possible al probable. Apunts Educació Física i Esports, 95, 75-81

13. Castellano, J., Perea, A., \& Blanco-Villaseñor, A. (2009). Has Soccer changed in the last three World Cups? In T. Reilly \& F. Korkusuz (Eds.), Science and Football VI (pp. 167-170). Antalya - Turkey: Routledge.
14. Castellano, J., Perea, A., \& Hernández-Mendo, A. (2008). Análisis de la evolución del fútbol a lo largo de los mundiales. Psicothema, 20(4), 928-932.

15. Cronbach, L. J., Gleser, G. C., Nanda, H., \& Rajaratnam, N. (1972). The dependability of behavioral measurements: Theory of generalizability for scores and profiles. New York: Wiley.

16. Duarte, R., Araújo, D., Fernandes, O., Fonseca, C., Correia, V., Gazimba, V., . . L Lopes, J. (2010). Capturing complex human behaviors in representative sports contexts with a single camera. Medicina (Kaunas), 46(6), 408-414.

17. Fleiss, J. L. (1981). Statistical methods for rates and proportions. New York: Wiley.

18. Grant, A., Williams, M., Reilly, T., \& Borrie, A. (1998). Analysis of the Successful and Unsuccessful Teams in the 1998 World Cup. Insight (FA Coaches), 2(1), 21-24.

19. Hernández-Mendo, A., Castellano, J., Camerino, O., Jonsson, G., Blanco-Villaseñor, A., Lopes, A., y Anguera, M.T. (2014). Programas informáticos de registro, control de calidad del dato, y análisis de datos. Revista de Psicología del Deporte, 23(1), 111-121.

20. Kuhn, T. (2005). Changes in Professional Soccer: a qualitative and quantitative study. In T. Reilly, J. Cabri \& D. Araújo (Eds.), Science and Football V (pp. 184-195). London: E \& FN Spon.

21. Lago, C. (2009). The influence of match location, quality of opposition, and match status on possession strategies in professional association football. Journal of Sports Sciences, 27(13), 1463-1469.

22. Lago, C., \& Martín, R. (2007). Determinants of possession of the ball in soccer. Journal of Sports Sciences, 25(9), 969-974.

23. Losada, J. (2012). Relación entre zonas y contextos de interacción en el fútbol de alto rendimiento: una aplicación multivariante. Motricidad. European Journal of Human Movement, 28, 171-183.

24. Mushquash, C., \& O'Connor, B. P. (2006). SPSS and SAS programs for generalizability theory analyses. Behavior Research Methods, 38(3), 542-557.

25. Norton, K. (2013). Match analysis in AFL, Soccer and Rugby Union: patterns, trends and similarities. In H. Nunome, B. Drust \& B. Dawson (Eds.), Science and Football VII: The Proceedings of the Seventh World Congress on Science and Football (pp. 153-159). London and New York: Routledge.

26. Pollard, R., Ensum, J., \& Taylor, S. (2004). Estimating the probability of a shot resulting in a goal: The effects of distance, angle and space. International Journal of Soccer and Science, 2(1), 50-55.

27. Pollard, R., \& Reep, C. (1997). Measuring the effectiveness of playing strategies at soccer. The Statistician, 46(4), 541-550.

28. Poyatos, F. (1994). La comunicación no verbal (tomo I). Madrid: Istmo.

29. Pratas, J., Volossovitch, A., \& Ferreira, A. P. (2012). The Effect of Situational Variables on Teams' Performance in Offensive Sequences Ending in a Shot on Goal. A Case Study. The Open Sports Sciences Journal, 5, 193-199.

30. Hernández-Mendo, A., Ramos-Pérez, F., y Pastrana, J.L. (2012). SAGT: Programa informático para análisis de Teoría de la Generalizabilidad. SAFE CREATIVE Código: 1204191501059.

31. Reina-Gómez, A., Hernández-Mendo, A., \& Fernández-García, J. C. (2010). Multi-facet design for goal scoring in soccer-7. Quality \& Quantity, 44(5), 1025-1035.

32. Sánchez-Algarra, P., \& Anguera, M. T. (2013). Qualitative/quanti- 
tative integration in the inductive observational study of interactive behaviour: impact of recording and coding among predominating perspectives. Quality \& Quantity, 47, 1237-1257.

33. Shavelson, R. J., Webb, N. M., \& Rowley, G. L. (1989). Generalizability Theory: New developments and novel applications. American Psychologist, 44, 922-932.

34. Taylor, J., Mellalieu, S., James, N., \& Shearer, D. (2008). The influ- ence of match location, quality of opposition, and match status on technical performance in professional association football. Journal of Sports Science, 26(9), 885-895.

35. Wallace, J. L., \& Norton, K. I. (2014). Evolution of World Cup soccer final games 1966-2010: Game structure, speed and play patterns. Journal of Science and Medicine in Sport, 17(2), 223-228. 